\title{
Constitutional asymmetry vs. sovereignty and self-determination
}

An alternative approach to autonomy claims

Maja Sahadžić *

Autonomy claims are a major aspect of federalism studies. Regardless of the importance of this topic, it has remained influenced to large extent by traditional studies in federalism. Thus, while emphasizing autonomy claims, most traditional federal theory remains rooted in two opposing concepts: the concept of sovereignty and the closely related right to self-determination. This paper challenges the traditional perspective by examining the question of sovereignty with reference to a dynamic notion of federalism. It addresses the notion of self-determination through an alternative approach involving the assessment of constitutional asymmetries, with the debate about constitutional asymmetries reviewed relative to multi-tiered systems and multinationalism. In relation to the major concepts examined, the paper demonstrates that the use of constitutional asymmetries in contemporary federal theory provides a more flexible approach to autonomy claims.

I. Introduction. 291

II. Sovereignty and the right to self-determination: two concepts to challenge .....292

1. Why is sovereignty outdated?

2. Self-determination: a painful pathway to separation .294

III. Introducing constitutional asymmetry as an alternative. 295

1. Multi-tiered is the new fashion ............................................................296

2. Aged, but sleek: nationalism and multinationalism ..................................297

3. Constitutional asymmetry as a circuit breaker ........................................297

IV. Conclusion .302

Zitiervorschlag: Maja Sahadžić, Constitutional asymmetry vs. sovereignty and self-determination, in: sui-generis 2017, S. 290

URL: $\quad$ sui-generis.ch/50

DOI: $\quad$ https://doi.org/10.21257/sg.5O

* Maja Sahadžić, PhD researcher, Government and Law Research Group, Faculty of Law, University of Antwerp, maja.sahadzic@uantwerpen.be. This paper is part of a research project funded by the Fundamental Research Foundation Flanders (Fonds Wetenschappelijk Onderzoek - FWO). 


\section{Introduction}

1 While Riker claims that the second half of the twentieth century was "the age of federalism", ${ }^{1}$ Gibson remarks that this "age of federalism" was less federal than the twenty-first century2. It has become apparent that having more than one government adjudicating over the same territory has become a familiar manifestation of power. Currently, a large portion of the world's population lives in federal systems. 3

2 A search of the literature revealed that traditional federal theory still revolves around old-fashioned concepts, which include, among others, the concept of sovereignty and the right to selfdetermination. Linked to this, traditional federalism scholarship appears to be unsuccessful in keeping up with the dynamics of the internal structure of states, in assuming that the federal state is made up of equal constituent units. Moreover, while the bedrock of traditional federal theory is formed by mono-national federal systems, it fails to acknowledge that many contemporary systems are essen-

\footnotetext{
William H. Riker, Federalism, origin, operation, significance (Fourth edn., Little Brown 1964) 1.

2 Edward L. Gibson, 'Federalism and Democracy in Latin America: Theoretical Connections and Cautionary Insights' in Edward L. Gibson (ed.), Federalism and democracy in Latin America (Johns Hopkins University Press 2004) 1.

3 The Forum of Federations enumerates 24 federal states in the world at the moment. Forum of Federations. "Formally constituted federalism [...] governs approximately 40 percent of the world's population and 45 percent of the world's landmass". Thomas O. Hueglin, 'Comparing federalism: Variations or distinct models?' in Arthur Benz and Jörg Broschek (eds.), Federal Dynamics: Continuity, Change, and the Varieties of Federalism (Oxford University Press 2013) 27. See also: Daniel J. Elazar, Exploring federalism (Tuscaloosa, Ala, University of Alabama Press 2006) 6.
}

tially multinational. In addition, such theories maintain the argument that symmetry serves as an integrative factor4, disregarding the fact that asymmetry seems to be obvious even in the most symmetrical of systems 5 . It is not only that traditional federalism scholarship suffers from being non-receptive to novel trends when applied in a contemporary context, but that it also limits the potential to bring a dynamic notion of federalism into effect and hinders the acceptance of opportunities to confront challenges with regard to a change in the understanding of autonomy claims.

3 The first aim of this paper is to respond to the theoretical challenges such as addressing the evolution in the internal structures of states and tackling the salience of identity, by focusing on the concept of sovereignty and the right to self-determination through the lens of dynamic federalism and multinationalism studies. The second aim of the paper is to introduce constitutional asymmetry as an alternative approach to selfdetermination claims, by exploring when asymmetry can act as such an alternative.

Charles D. Tarlton, 'Symmetry and Asymmetry as Elements of Federalism: A Theoretical Speculation' [Southern Political Science Association] 27 The Journal of Politics 861. Also: Francesco Palermo, 'Asymmetries in Constitutional Law - An Introduction' in Francesco Palermo, Carolin Zwilling and Karl Kössler (eds), Asymmetries in Constitutional Law, Recent Developments in Federal and Regional Systems (Europäische Akademie Bozen/Accademia Europea Bolzano 2009) 15 .

5 Frank Delmartino, 'New Dimensions of Asymmetry in (Quasi-) Federal States and in the European Union' in Francesco Palermo, Carolin Zwilling and Karl Kössler (eds), Asymmetries in Constitutional Law, Recent Developments in Federal and Regional Systems (Europäische Akademie Bozen/Accademia Europea Bolzano 2009) 38. Also: Palermo (Fn. 4), 17. 
4 The paper starts with a brief discussion of sovereignty and self-determination, applying the notion of dynamic federalism, employing studies in multinationalism and arguing for more fluidity in addressing the concepts. It proceeds to introduce constitutional asymmetries in order to provide fresh perspectives on multi-tieredness and multinationalism. This is followed by a debate on constitutional asymmetry considered as an alternative way to address autonomy claims, before some concluding remarks. Finally, the paper focuses on the potential of constitutional asymmetry against autonomy claims.

\section{Sovereignty and the right to self-determination: two concepts to challenge}

5 One major theoretical issue that has dominated a wide range of fields for many years concerns the concept of sovereignty. Traditional and contemporary federal theories are no exception. To date, federalism scholarship has implied that the idea of sovereignty is essential for the existence of states. The backbone of this matter concerns the question of whether sovereignty is shared or not, and - whether it is or is not - to which level it belongs. Nevertheless, a definitive legal answer to the question of the way in which sovereignty is beholden to the power of states is sometimes difficult to establish. This is likely to be related to specificities in the internal organization of the states in question. Another theoretical issue is that of the concept of selfdetermination, which was associated with sovereignty until the end of the twentieth century, giving the impression of an integral relationship. ${ }^{6}$ Undoubtedly, the right to self-determination is tied in large part to the issue of how sovereignty is shared.7 Notwithstanding their proximity, however, the two concepts are dissimilar at a practical level and continually competing. ${ }^{8}$ Sovereignty is made a central issue by the state, while selfdetermination is central to the people. 9 Thus far, attempts to mediate the differences between the two concepts have failed, as both are preemptory norms of international law. ${ }^{10}$

6 As a result of this deadlock, this paper proposes that the debate about sovereignty and self-determination should be given fresh prominence. Firstly, it is argued that the concept of sovereignty should be addressed with more flexibility in order to accommodate new contexts. Secondly, the paper suggests that the concept of self-determination should receive softer treatment that recognizes constitutional asymmetries. The following sections address these two issues: a dynamic approach to federalism as a response to the question of sovereignty; and the importance of identity as a prerequisite to self-determination claims.

$6 \overline{\text { Banai Ayelet, 'Freedom beyond the threshold: }}$ self-determination, sovereignty, and global justice' [Co-Action Publishing] Ethics \& Global Politics, Vol 8, Iss o, Pp 1-21 (2015) 1, 28.

7 André Lecours, 'Sub-state Nationalism in the Western World: Explaining Continued Appeal' [Routledge] 11 Ethnopolitics 268, 282.

8 Neil MacFarlane and Natalie Sabanadze, 'Sovereignty and self-determination: Where are we?' [SAGE Publications Ltd] 68 International Journal 609, 615 .

9 Nora Y.S. Ali, 'For Better or For Worse? The Forced Marriage of Sovereignty and SelfDetermination' 47 Cornell International Law Journal, 419.

10 Ibid. 


\section{Why is sovereignty outdated?}

7 At the outset, this paper challenges traditional studies in attempting to show that, under a dynamic notion of federalism, sovereignty no longer plays a critical role. This is because dynamic federalism identifies federalism with a process, ${ }^{11}$ thus shaping the idea of federalism as a dynamic rather than static concept. ${ }^{2}$ In effect, the process of federalism involves a number of different political communities engaged in bargaining for the accommodation of differences. As such, the dynamic model enables new tiers to be developed between the central and local levels, unlike the static model of federalism. ${ }^{13}$ With this in mind, there are two key aspects that need to be considered.

8 The first key aspect suggests that there are a variety of systems that fall under the dynamic notion of federalism, 14 which reach beyond the traditional federal theory classification of states into unitary, federal, and confederate entities. This model might certainly have clarity as an advantage; however, it is not in line with a contemporary range of political and constitutional systems. 15 This is due to the fact that the constitutional structure of contemporary states does not always reveal the true nature of the particular state, and might mean that while a

11 C.J. Friedrich, Trends of federalism in theory and practice (Praeger 1968) 7.

12 Ibid.

13 I.D. Duchacek, Comparative federalism: the territorial dimension of politics (Holt, Rinehart and Winston 1970) 279.

14 Friedrich (Fn. 11), 7. Also, Patricia Popelier, The need for sub-national constitutions in federal theory and practice : the Belgian case (2012) 43.

15 Patricia Popelier and Koen Lemmens, The Constitution of Belgium. a contextual analysis (Oxford, Hart Publishing 2015) 72. Also: Patricia Popelier, 'Subnational multilevel constitutionalism' 6 Perspectives on federalism 1, E. state might have been established as a unitary entity, it operates as a federal state, or vice versa. ${ }^{16}$ Under such circumstances, contemporary federal arrangements may be identifiable, although only implicitly present within quasi-federal states, regionalized unitary states, or even within a transnational setting. ${ }^{17}$ This allows us to conclude that not only is it not necessary to delineate federal systems, ${ }^{18}$ it is no longer accurate to do So. ${ }^{19}$

9 The second key aspect is that contemporary states reveal vibrant processes, resulting in a constant search for autonomy and the existence of counterbalancing tensions to this aim. ${ }^{20}$ Linked with territorially based differences, particular political groups are increasingly likely to establish their own political authority in a given territory ${ }^{21}$, which competes with the traditional notion of sovereignty. This can be observed, for instance, in Bosnia and Herzegovina, in Belgium, Canada, India, Italy, Spain, and in the United Kingdom.

10 As shown above, under particular circumstances, contemporary systems com-

16 William S. Livingston, 'A Note on the Nature of Federalism' [Academy of Political Science] 67 Political Science Quarterly 81, 84. Also: Palermo (Fn. 4), 14.

17 Delmartino (Fn. 5), 38. Also: Palermo (Fn. 4), 17.

18 Popelier (Fn. 14), 43.

19 Popelier (Fn. 15), 6.

20 Liesbet Hooghe and Gary Marks, 'Types of Multilevel Governance' in Henrik Enderlein, Sonja Wälti and Michael Zürn (eds), Handbook on Multi-Level Governance (Edward Elgar Publishing 2012) 17.

21 Alfred Stepan, 'Towards a New Comparative Politics of Federalism, Multinationalism, and Democracy: Beyond Rikerian Federalism' in Edward L. Gibson (ed.), Federalism and Democracy in Latin America (Johns Hopkins University Press 2004) 39. 
bine shared rule and self-rule elements, beyond the traditional concept of sovereignty. Under the impact of continuous autonomy claims, systems are created that are not easily delineated. These issues point to the notion that the concept of sovereignty is losing its importance. ${ }^{22}$

\section{Self-determination: a painful pathway to separation}

11 One of the reasons why selfdetermination became a pivotal concept in federalism studies is due to its overwhelming interconnection with nationalist movements. ${ }^{23}$ As nations are viewed as territorially determined groups with a shared identity in the background, they naturally follow the self-determination path. ${ }^{24}$ This is because the idea of selfdetermination is closely connected to the fundamental right of a nation to decide on its own future. ${ }^{25}$ Extensive research has confirmed that there have been quite a few cases in which groups with a distinct identity have come into conflict with the territorial integrity of the state. 26 These include, for example, the Basque, Catalan, Flemish, Scottish, and Quebecois nationalist movements. ${ }^{27}$

Reflecting on the identity issues arising during recent decades reveals the gap between the old and new concepts of federalism, as well as the attempt to adjust the old concepts to new events. ${ }^{28}$ As sub-

22 Popelier (Fn. 14), 43.

23 Lecours (Fn. 7), 269.

24 See: Eric Taylor Woods, 'Beyond multination federalism: Reflections on nations and nationalism in Canada' [SAGE Publications] 12 Ethnicities 270, 272.

25 Lecours (Fn. 7), 272.

26 MacFarlane and Sabanadze (Fn. 8), 615.

27 Lecours (Fn. 7), 268.

28 Manuela Guilherme and Gunther Dietz, 'Difference in diversity: multiple perspectives on multi- national identities posed recurring challenges to territorial integrity, states began to introduce constraints to the concept of self-determination. ${ }^{29}$ In this respect, to silence self-determination claims, traditional federal theory introduced the idea of common citizenship, considered as a common and underlying identity, additional to any subnational identity claims. $3^{\circ}$ Despite such attempts, the aim has been defied by the establishment of models of what Kymlicka refers to as "multinational citizenship". ${ }^{1}$ This is because subnational identities appear to manifest the singularity of belonging to a distinct group, $3^{32}$ which runs parallel with a sentiment associated with territorial belonging, 33 and they develop their individual identity within different layers of belonging, especially in contemporary state structures. 34

13 A particular issue for multinational states has always been how to reconcile national identity with territorial integrity. 35 Here, it is suggested that the employ-

cultural, intercultural, and transcultural conceptual complexities' [Taylor \& Francis Ltd] 10 Journal of Multicultural Discourses 1, 2.

29 Such as theories of recognition. Ali (Fn. 9), 428.

3o Lovise Aalen, 'Ethnic Federalism and SelfDetermination for Nationalities in a SemiAuthoritarian State: the Case of Ethiopia' 13 International Journal on Minority and Group Rights 243, 244.

31 Will Kymlicka, 'Multicultural citizenship within multination states' [SAGE Publications] 11 Ethnicities 281, 282.

32 Consult: Ernest Gellner, Nations and nationalism (Oxford, Blackwell 1993). Also, see the number of terms Tierney uses to refer to groups. In: Stephen Tierney, Constitutional law and national pluralism (Oxford, Oxford University Press 2006) 5.

33 Livingston (Fn. 16), 85. Also: Michael Burgess, Comparative federalism. theory and practice (London, Routledge 2006) 143.

34 Ferran Requejo, 'Federalism and national groups' [Blackwell Publishers Ltd] 53 International Social Science Journal 41, 41.

35 MacFarlane and Sabanadze (Fn. 8), 615. 
ment of the notion of constitutional asymmetries can allow for a softer response compared to more exclusionary claims to the right to self-determination. At least two arguments for this come to mind: first, constitutional asymmetries are less likely to cause discordance in the structure of the state; 36 and, second, a number of studies suggest constitutional asymmetries can form the basis of a favorable view of the accommodation of subnational identity, as they support legitimacy and stability in states that exhibit multinational features, 37 with examples including Belgium, Canada, India, Russia, Spain ${ }^{8}$, and the United Kingdom. 39

\section{Introducing constitutional asymmetry as an alternative}

14 To date, federalism studies have mainly tended to focus on how to preserve the traditional idea of the federal state, while setting aside the issue of federal dynamics. Three principles are found to be central to federal states considered in such a way: equality, mono-nationalism, and symmetry. With regard to the first, a number of traditional studies have defined the federal state as comprised of

$36 \overline{\text { Alfred Stepan, 'Comparative Theory and Political }}$ Practice: Do We Need a 'State-Nation' Model as Well as a 'Nation-State' Model?1' [Blackwell Publishing Ltd] 43 Government and Opposition 1, 6.

37 Kham Khan Suan Hausing, 'Asymmetric Federalism and the Question of Democratic Justice in Northeast India' [Routledge] 13 India Review 87, 89.

38 The paper has been submitted before the referendum in Catalunya in 2017. These events reveal a deep political crisis, but in legal terms, the outcome of the crisis is still to be determined. Moreover, the paper does not address Catalunya only, but other sub-national entities in Spain as well, namely, the Basque Country, Navarre, Galicia, etc.

39 Ibid. identical constituent units, equal in their relationship with each other and all recognizing a centralized power. 40 With regard to the second, traditional studies in federalism have concentrated on mononational types of federal states, 41 and third, symmetry has been used as a mechanism for the integration of all groups, $4^{2}$ as it was assumed that this would safeguard the stability of the federal system. 43

15 The most obvious findings to emerge from the analysis of the literature are that traditional federal theory links symmetry to mono-national entities and to their processes of nation-building, 44 and that it uses the term 'symmetry' as a synonym for 'equality', while 'asymmetry' is taken as a synonym for 'inequality'. 45 These are not the only obstacles in applying traditional federal theory to contemporary states with asymmetrical arrangements, but they do present some of the greatest challenges to understanding

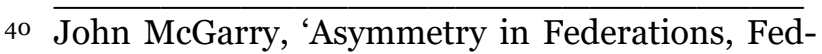
eracies and Unitary States' [Routledge] 6 Ethnopolitics 105, 105.

41 Feran Requejo, 'Decentralization and Federal and Regional Asymmetries in Comparative Politics' in Feran Requejo and Klaus Jürgen Nagel (eds), Federalism Beyond Federations, Asymmetry and Processes of Resymmetrisation in Europe (Ashgate 2011) 8.

42 Charles D. Tarlton, Symmetry and Asymmetry as Elements of Federalism: A Theoretical Speculation (Southern Political Science Association 1965). Also: Palermo (Fn. 4), 15.

43 Similar: Burgess (Fn. 33), 212.

44 Ferran Requejo, 'Federalism and the Quality of Democracy in Plurinational Contexts: Present Shortcomings and Possible Improvements' Paper prepared for the ECPR Joint Sessions of Workshops 2001 Workshop: Centres and Peripheries in a Changing World 26, 12.

45 Brendan O'Leary, 'Thinking about asymmetry and symmetry in the remaking of Iraq' in Mark Weller and Katherine Nobs (eds.), Asymmetric Autonomy and the Settlement of Ethnic Conflicts (University of Pennsylvania Press 2011) 184. 
the interaction of multiple tiers of government, multinationality, nationality, and constitutional asymmetries.

The paper thus proposes a new approach to overcome the drawbacks of traditional federalist theory. The brief discussion of sovereignty and self-determination will now be used as a point of reference to advance further considerations, pointing to ideas concerning a dynamic approach to federalism that allows the exploration of new types of state systems in a less restrictive way. In addition, considering the implications of identity and nationalism, the paper proceeds to position constitutional asymmetry as a contemporary, softer, and more appropriate tool for the accommodation of differences, compared to self-determination. To this end, the following section introduces the concept of multi-tiered systems that develop territorially based divisions tied to differences in identity, and which accordingly produce diverse asymmetrical effects in relationships between and among the tiers. 46

\section{Multi-tiered is the new fashion}

17 One of the arguments made here is that, at present, the traditional division of the forms of states into unitary, federal, and confederate models is not appropriate. One possible explanation for this division might be that traditional federal theory greatly relies on 'model' federations, such as Australia, Germany, Switzerland47,

46 Stepan (Fn. 21), 40.

47 Stepan acknowledges that many other authors call the Swiss Confederation multinational, but prefers to call the Swiss Confederation the "statenation" rather than the "multinational state". $\mathrm{He}$ states that "Protestand and Catholic differences are linguistically cross-cutting rather than compounding. $[\mathrm{N}]$ one of the parties that have been in and the US, but, at the same time, omits to address recent developments in the internal structure of states such as Bosnia and Herzegovina, Belgium, Italy, Spain, and the United Kingdom..$^{8}$ In addition, it could conceivably be hypothesized that, in 'model' federations, a uniform status for subnational entities is the rule. 49

18 In the first case, contemporary federal systems can mainly be characterized as states which are in the process of fragmenting50 or, more positively stated, "holding together", ${ }^{51}$ in either case tending to accommodate emerging differences and hold themselves together through federal arrangements. 52 Importantly, these states develop intermediary tiers of government that operate between the central and local levels in order to address intrastate differences, thus creating a multi-tiered system. A system is considered multi-tiered when the central level is mixed between subnational entities with lawmaking power, combining the idea of shared rule and self-rule.53 Moreover, under relentless

the 'magic formula' four-party power-sharing coalition [...] is built around a single language, and no significant party advocates secession". Ibid.

48 Usually referred to as "coming together" federations, based on Riker's voluntary federal bargaining by autonomous entities. See: ibid. Popelier (Fn. 15), 4. Requejo (Fn. 41), 7.

49 Richard Bird, M. and Robert D. Ebel, 'Subsidiarity, Solidarity and Asymmetry: Aspects of the Problem' in Richard Bird, M. and Robert D. Ebel (eds), Fiscal Fragmentation in Decentralized Countries, Subsidiarity, Solidarity and Asymmetry (Edward Elgar Publishing 2007) 11.

50 H. Obinger, S. Leibfried and F.G. Castles, Federalism and the Welfare State: New World and European Experiences (Cambridge University Press 2005) 8.

${ }^{51}$ Stepan (Fn. 21), 33.

52 Ibid.

53 However, it has to be noted that some of the systems mentioned previously, have less-developed elements of shared rule in their systems, namely, 
autonomy claims and continuous endeavours to accommodate differences, multi-tiered systems allow for differential status among and between the tiers of government. Given these points, multi-tiered systems clearly perform under a dynamic approach to federalism, by employing shared rule and self-rule and by ensuring a distinct status for some tiers of government, which places them at a distance from the concept of sovereignty.

\section{Aged, but sleek: nationalism and multinationalism 54}

19 Coupled with the idea of multi-tiered systems, another point to consider is that the concept of mono-national federal systems is inappropriate in traditional federal theory. This may be explained by the fact that traditional federalism scholarship presupposes that national states are the main and lowest unit of comparison. 55 This makes it possible to hypothesize that this concept is likely to be applied in states in which federalism is inspired by "model federations" and where latent ethnocentrism refuses to recognize distinct identities. 56

Italy, Spain, and the United Kingdom. In Italy, shared rule is limited to executive and fiscal control and consultations over amending the constitution. In Spain, shared rule may be traced under fiscal matters and constitutional reform. In the United Kingdom, compared to Scotland and Wales, Northern Ireland has lesser shared rule elements. Liesbeth Hooghe, Gary Marks and Arjan H. Schakel, The Rise of Regional Authority, A comparative study of 42 democracies (Routledge 2010) 146.

54 Multinationalism can be described as territorially based differences built on linguistic, religious, cultural, ethnic, and other identities, where significant groups with one or more identities claim important political autonomy around these differences. Stepan (Fn. 21), 39.

55 Hooghe, Marks and Schakel (Fn. 53), 2.

56 Will Kymlicka, 'Is federalism a viable alternative to secession?' in Percy B. Lehning (ed.), Theories of Secession (Routledge 2005) 128.
20 In this respect, distinct from previous scholarship, this study argues that groups with a distinct identity will test the mono-national idea of the state, as their main concern is to press for the accommodation of differences. 57 In such cases, states will respond by introducing new tiers of government, seemingly in order to anticipate self-determination claims. This is, for example, observable in the Federation of Bosnia and Herzegovina, as well as the Republic of Srpska within Bosnia and Herzegovina, Flanders and Wallonia in Belgium, the Aosta Valley and South Tyrol in Italy, the Basque Country, Catalunya and Galicia in Spain, and Northern Ireland, Scotland and Wales in the United Kingdom, among other examples. $5^{8}$ Such a response supports both the conceptual premise that the accommodation of differences is pursued through different tiers of government, and that compared to selfdetermination claims, states resort to less formidable options to accommodate differences.

\section{Constitutional asymmetry as a circuit breaker}

21 The changes experienced in the internal structure of states over the past decades have led to increased interest in the study of constitutional asymmetries.59 Consequently, contemporary research has

57 Tierney (Fn. 32), 9.

58 S. Piattoni, The Theory of Multi-level Governance: Conceptual, Empirical, and Normative Challenges: Conceptual, Empirical, and Normative Challenges (OUP Oxford 2010) 7.

59 Asymmetries emerge in two different types: De facto or political asymmetry is defined as practices and relationships based on linguistic, religious, cultural, ethnic, social, economic, political, and other differences between subnational entities, and between subnational entities and the central level. De jure, constitutional, or formal asymme- 
raised intriguing questions regarding the nature and extent of asymmetry in specific systems. Despite this, little progress has been made in considering the employment of constitutional asymmetries as an alternative approach to selfdetermination claims in connection to sovereignty. The likely cause for this shortfall is a difficulty in applying federal theory concepts that are currently available to the contemporary dynamic environment.

The paper contests the notion that symmetry should be considered as one of the central features of traditional federal theory. This concerns the fact that traditional federal theory uses the model of symmetry as a justification for encourag-

tries, are differences embedded in constitutional and legal processes, producing an unequal positioning of subnational entities under the law. When de facto asymmetries are entrenched in the legal framework, they materialize into de jure asymmetries, formally treating subnational entities differently under the law. See, for example: Ronald L. Watts, Comparing federal systems (Montreal, Que., McGill-Queen's University Press 2 ed. 1999) 63. Burgess (Fn. 33), 216. Robert Agranoff, Accommodating diversity: asymmetry in federal states ( Nomos 1999) 16. Wilfried Swenden, Federalism and regionalism in Western Europe. a comparative and thematic analysis (Basingstoke, Palgrave Macmillan 2006) 48. Popelier and Lemmens (Fn. 15), 80. Mark Weller, 'Introduction' in Mark Weller and Katherine Nobbs (eds), Asymmetric Autonomy and the Settlement of Ethnic Conflicts (University of Pennsylvania Press 2011) 1. John McGarry, 'Asymmetric Autonomy in the United Kingdom' in Mark Weller and Katherine Nobs (eds), Asymmetric Autonomy and the Settlement of Ethnic Conflicts (University of Pennsylvania Press 2011) 148. Nancy G. Bermeo, 'Conclusion: The Merits of Federalism' in U.M. Amoretti and N.G. Bermeo (eds), Federalism and Territorial Cleavages (Johns Hopkins University Press 2004) 263. Stepan, 'Towards a New Comparative Politics of Federalism, Multinationalism, and Democracy: Beyond Rikerian Federalism' 40. ing integration. ${ }^{60}$ This is likely to be related to such symmetry being perceived as a suitable mechanism for dealing with differences within states with federal arrangements. ${ }^{61}$

23 In this respect, first and foremost, current studies in federalism indicate that systems that accommodate differences in identity are prone to employ asymmetrical solutions in order to accommodate diverse interests and to protect the rights of subnational entities. ${ }^{62}$ Moreover, systems accommodating substantial diversity tend to be the most asymmetrical.63 There are ways to address constitutional asymmetry: (1) the delineation of subnational units; (2) representation in the central level institutions; and (3) the distribution of power and competences.

24 Firstly, regarding the delineation of subnational units, in Belgium, the institutional design varies with regards to regions and communities. Flanders incorporated the Flemish Region and the Flemish Community including the Dutch-speaking population in Brussels, while the Walloon Region in Wallonia is separated from the French-speaking

60 Tarlton, Symmetry and Asymmetry as Elements of Federalism: A Theoretical Speculation.

61 Klaus Jürgen Nagel and Ferran Requejo, 'Conclusions: Asymmetries and Decentralisation Processes - Comparative Comments' in Ferran Requejo and Klaus Jürgen Nagel (eds.), Federalism Beyond Federations, Asymmetry and Processes of Resymmetrisation in Europe (Ashgate 2011) 249.

62 Luis Moreno, 'Asymmetry in Spain: Federalism in Making?' in Robert Agranoff (ed.), Accommodating Diversity: Asymmetry in Federal States (Nomos Verlagsgesellschaft 1999) 149

63 Agranoff (Fn. 59), 14 Robert Agranoff, 'Power Shifts, Diversity and Asymmetry' in Robert Agranoff (ed.), Accommodating Diversity: Asymmetry in Federal States (Nomos Verlagsgesellschaft 1999). 
Community 64 that includes the Frenchspeaking population in Brussels. As well, the German-speaking community does not have corresponding regional institutions.

Secondly, regarding the representation, in the states with federal arrangements, which have the bicameral legislature, the representation of sub-national entities in the central level institutions may display asymmetrical features. Most likely, the first chamber represents the population and the second chamber represents a sub-national entity. Bosnia and Herzegovina proves to be different in an important way. The second chamber in Bosnia and Herzegovina represents three constituent/constitutive ${ }^{65}$ peoples based on their territorial affiliation. 66

Another issue connected to constitutional asymmetries in representation can be tracked down in the emerging question whether representatives from more autonomous sub-national entities should be restricted from voting in the central level institutions on matters over which the central level does not have powers and

64 Ronald L. Watts, 'The Theoretical and Practical Implications of Asymmetrical Federalism' in Robert Agranoff (ed.), Accommodating Diversity: Asymmetry in Federal States (Nomos Verlagsgesellschaft 1999) 38 .

65 In Bosnia and Herzegovina these two terms are often discussed without a clear theoretical and practical position on their meaning. The first one is used to express three ethnic-national communities (Bosniaks, Croats, and Serbs) as component parts of the state, while the second one is used to point at three ethnic-national communities as creators of the Bosnia and Herzegovina. The first one is in more frequent use in foreign languages. The second one is in more frequent use in official languages in Bosnia and Herzegovina. Throughout the text I will use the first version.

66 Constitution of Bosnia and Herzegovina (1995) See Article IV. competences in that distinct entity. ${ }^{67}$ This question has been raised in the United Kingdom in the light of Scottish devolution. In 2015, it was already implemented with amendments in the House of Common's Standing Orders giving English members of parliament a veto in matters concerning English affairs. However, there is a similar example at the sub-national entity level in the Kingdom of Belgium. In the Flemish parliament, members that are elected in the Brussels district are not allowed to vote on regional matters, because the Flemish Region has no competences to vote on regional matters in Brussels.

27 Thirdly, regarding the distribution of power and competences, in Belgium, the German-speaking community does not have the same powers as the Dutchspeaking and the French-speaking communities as it cannot exercise language competences, with the exception of the use of language in education. But, it exercises some regional competences owing to the fact that the Walloon Region has transferred these to the Germanspeaking community. ${ }^{68}$ Tracing on this, the French-speaking community can choose to transfer the exercise of its powers to the Walloon Region and the

67 R.L. Watts, Queen's University. Institute of Intergovernmental Relations and Queen's University. School of Policy Studies, Comparing Federal Systems (School of Policy Studies, Queen's University 2008) 130. Also, Ronald L. Watts, 'Contemporary Views on Federalism' in Bertus De Villiers (ed), Evaluating Federal Systems (Jutta \& Company 1994) 12.

68 Hugues Dumont and others, 'Kingdom of Belgium' in Akhtar Majeed, Ronald L. Watts and Douglas M. Brown (eds.), Distribution of Powers and Responsibilities in Federal Countries (McGill-Queen's University Press 2005) 48. Also: Jan Wouters, Sven Van Kerckhoven and Maarten Vidal, 'The dynamics of federalism: Belgium and Switzerland compared' (2014) 8. 
French-speaking Community Commission in Brussels. However, constitutional provisions do not grant the same powers to the Flemings who merged their institutions. ${ }^{69}$

In Canada, constitutional asymmetry in the distribution of power and competences is displayed in the linguistic advantages of Quebec, exercised in education, legislature, courts, and the civil law application. $7^{\circ}$ In Italy, South Tyrol negotiated its competencies and finances bilaterally with the central level.71 The Spanish constitution provides an optional autonomy system, 72 a fast-track route for historic regions, and a slow-track route for other regions, 73 as well as different fiscal agreements, as have been established for the Basque Country and the Chartered Community of Navarre.74 While the central level government in Spain manages the most important taxes for regions, the Basque Country and Navarre collect all taxes except for tobacco, petroleum, and customs duties.75 In the United Kingdom, the set of competencies differs between Scotland (in relation to basic income tax), Northern Ireland (in relation to legislation concerning employment), and Wales, which has execu-

69 Popelier and Lemmens (Fn. 15), 80

70 Watts, Relations and Studies (Fn. 67), 130. Also: Swenden (Fn. 59), 221 This position might be regarded as similar to Scotland in the United Kingdom.

71 Francesco Palermo and Alex Wilson, 'The multilevel dynamics of state decentralization in Italy' 12 Comparative European Politics 510, 511.

72 Luis López Guerra, 'El modelo autonómico' Revista Catalana de Derecho Público, Autonomies, 171 Cited in: Violeta Ruiz Almendral, 'Sharing Taxes and Sharing the Deficit in Spanish Fiscal Federalism' 10 eJournal of Tax Research 88, 91.

73 Swenden (Fn. 59), 63.

74 Watts, Relations and Studies (Fn. 67), 130.

75 Swenden (Fn. 59), 65. tive powers to address the use of the Welsh language. 76

29 It follows that an association between the multi-tiered system and multinationality raises an expectation that asymmetry will be the rule in multi-tiered multinational systems. 77 This relationship may be explained by the fact that constitutional asymmetries are often linked to multinationality, as they rely on asymmetric solutions to preserve the unity of the system, while addressing diversity. This potentially produces diverse effects in the interrelationship between the tiers of such systems.

30 Due to length constraints, this paper cannot provide a comprehensive review of positive and negative aspects of constitutional asymmetry. However, it can provide substantial arguments to support the hypothesis that constitutional asymmetries should be taken into consideration as an alternative route to selfdetermination. The present findings are significant in at least two major aspects. First, the leading characteristic of a multi-tiered multinational system that exhibits asymmetrical features is the tailormade accommodation of diversity. $.^{78} \mathrm{Sec}-$ ond, the lack of success in accommodating autonomy claims might further stim-

76 Ibid.

77 Rainer Bauböck, 'United in Misunderstanding? Asymmetry in Multinational Federations' ICE Working Paper Series, 14.

78 Similar in: Michael Burgess, 'The Paradox of Diversity - Asymmetrical Federalism in Comparative Perspective' in Francesco Palermo, Carolin Zwilling and Karl Kössler (eds.), Asymmetries in Constitutional Law, Recent Developments in Federal and Regional Systems (Europäische Akademie Bozen/Accademia Europea Bolzano 2009) 34 . 
ulate centrifugal forces.79 Thus, it can be suggested that having constitutional asymmetry within reach, equates to flexibility in the institutional design process, including successive accommodation processes. ${ }^{80}$ In addition, having constitutional asymmetry at one's disposal can be said to imply abandoning forceful homogenization and supporting the power to choose, ${ }^{81}$ ultimately preventing the system from falling apart. ${ }^{82}$ In both cases, constitutional asymmetries in multitiered multinational systems are representative of federal dynamics, but they do not produce instability by definition. It is suggested that they in fact encourage the dynamic stability of the system, ${ }^{83}$ as stability in these systems is founded on mutual relationships between a complex set of actors and processes. ${ }^{84}$

31 In addition, complexity can act as a shock absorber, dispersing the tension arising due to compound state structures

79 McGarry, 'Asymmetry in Federations, Federacies and Unitary States' 112.

8o Stefan Wolff, 'Cases of Asymmetrical Territorial Autonomy' in Mark Weller and Katherine Nobs (eds.), Asymmetric Autonomy and the Settlement of Ethnic Conflicts (University of Pennsylvania Press 2011) 24.

81 The power to choose for subnational entities is in the nature of multi-tiered multinational systems. See: Bauböck (Fn. 77), 22.

82 John McGarry and Brendan O'Leary, 'Territorial pluralism: its forms, flaws, and virtues' in Ferran Requejo and Miguel Caminal Badia (eds.), Federalism, Plurinationality and Democratic Constitutionalism: Theory and Cases (Routledge 2012) 40.

83 Arthur Benz and Jörg Broschek, 'Conclusion: Theorising federal dynamics' in Arthur Benz and Jörg Broschek (eds.), Federal dynamics, Continuity, change, and the varieties of federalism (Oxford University Press 2013) 382.

84 C. I. Zuber, 'Understanding the Multinational Game: Toward a Theory of Asymmetrical Federalism' 44 Comparative Political Studies 546, 548. through a network of paths leading in different directions. ${ }^{85}$ This combination of findings provides support for the conceptual premise that as long as there is a margin for 'slippery slope', the threat that constitutional asymmetries will pose to the stability of the system will be tolerable. 86 In addition, constitutional asymmetries may act as transitional or permanent solutions, but will still be appropriate for reaching a turning point in an agreement on potential future relationships among tiers of government.

32 In summary, if they are institutionalized, constitutional asymmetries may act as a tool for the accommodation of multinationality in multi-tiered multinational states. Nonetheless, a further study with more focus on how constitutional asymmetries should address diversity is suggested, as the question of how to institutionalize differences remains. ${ }^{87}$ The analysis of existing asymmetrical multi-tiered multinational systems revealed that there are three main groups of constitutional asymmetries that can be applied. ${ }^{88}$ The first group concerns the legally embedded differential status of one or more subnational entities in multi-tiered systems. The second group addresses the distribution of power and competencies among subnational entities in the multi-tiered system. The third group makes reference

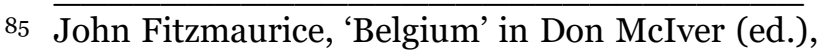
The politics of multinational states (Palgrave Macmillan 1999) 105. Cited in: Bauböck (Fn. 77), 16.

86 Bauböck (Fn. 77), 19. Bauböck describes a slippery slope as a path "along which multinational federations may glide down towards dissolution".

87 Burgess (Fn. 78), 21.

88 Maja Sahadžić, '"New federal systems": multitiered, multinational, asymmetrical' Tijdschrift voor bestuurswetenschappen \& publiekrecht 221, 228. 
to the extent and level of fiscal autonomy of a specific subnational entity.

Nonetheless, some limitations in applying constitutional asymmetries must be kept in mind. Bringing constitutional asymmetries into play excludes maximalist and instant demands, as the former approach will not recognize 'take it or leave it' offers. Quite the opposite, demands are negotiated and settled over a period of time. Nevertheless, in the case of any urgent need for negotiations, and when an agreement cannot be reached, sides can always opt to negotiate at a favorable pace and speed, approaching the same aims and objectives. In spite of the potential harmful effects, constitutional asymmetry still remains an option for the accommodation of diversity, ${ }^{89}$ as it allows the opportunity to compromise, assuming that sides are willing to do so. ${ }^{90}$

\section{Conclusion}

34 The present paper aimed to address the gap between traditional and contemporary federal theory in researching mechanisms for the accommodation of diversity. As the issue of autonomy claims has thus far received little attention in the literature, the paper focused on developing a more profound understanding of why the traditional study of federalism appears insensitive to contemporary federal dynamics. The paper has responded to the theoretical challenges by connecting a dynamic approach to federalism with the question of sovereignty, and address-

89 Burgess in: Palermo, Zwilling and Kössler (Fn. 78), 34.

90 Wolff in: M. Weller and K. Nobbs, Asymmetric Autonomy and the Settlement of Ethnic Conflicts (University of Pennsylvania Press, Incorporated 2011) 24 . ing the importance of identity as a prerequisite for self-determination claims. By providing flexibility in both concepts, the paper has created a basis for a debate about constitutional asymmetries as an alternative approach to addressing autonomy claims. The framework proposed allows the exploration of when asymmetrical solutions can act as an alternative to self-determination claims. Finally, the concept presented here is open to criticism, being merely a broadly argued thesis requiring further thought and welcoming feedback. 